Gut, 1984, 25, 611-618

\title{
Analysis of the molecular state of HBV-DNA in the liver and serum of patients with chronic hepatitis or primary liver cell carcinoma and the effect of therapy with adenine arabinoside
}

\author{
M J F FOWLER, J MONJARDINO, I V D WELLER, A S F LOK, \\ AND H C THOMAS
}

From the Departments of Physiology and Medicine, Royal Free Hospital School of Medicine, London

SUMMARY The pattern of replicative intermediates seen in the liver of $\mathrm{HBe}$ antigen and antibody positive patients was determined. During the phase of $\mathrm{HBe}$ antigenaemia the $3.2 \mathrm{~Kb}$ species of HBV-DNA (complete HBV genome) is present in the liver but not in the serum. When $\mathrm{HBe}$ antigen to antibody seroconversion occurs, either spontaneously or during antiviral therapy, the $3 \cdot 2 \mathrm{~Kb}$ and lower molecular weight intermediates disappear from the liver and the $3.2 \mathrm{~Kb}$ band appears transiently in the serum. Integrated HBV-DNA was found in one of 15 patients during the period of $\mathrm{HBe}$ antigenaemia and in three of seven patients in the $\mathrm{HBe}$ antibody positive phase of the chronic infection before detection of primary liver cell carcinoma. Integrated sequences were found in tumour tissue of two patients with primary liver cell carcinoma who were anti-HBc positive but were absent from the tissues of two patients developing primary liver cell carcinoma at a late stage of autoimmune liver disease. These studies suggest that integration of the HBV genome occurs rarely or in only a small proportion of hepatocytes during the early (HBe antigen positive) phase of infection in Caucasians. They also show that not all primary liver cell carcinomas necessarily contain HBV-DNA.

The epidemiological evidence suggesting that hepatitis B virus (HBV) is an aetiological agent for primary liver cell carcinoma is strong. ${ }^{12}$ There is a positive correlation between the geographic prevalence of chronic $\mathrm{HBV}$ infection and that of primary liver cell carcinoma, ${ }^{34}$ multiple studies show an excess incidence of HBs antigen positivity in primary liver cell carcinoma cases compared with normal individuals and patients with other tumours, ${ }^{5-7}$ and a prospective study in Taiwan has shown that $\mathrm{HBs}$ antigen positive individuals are 390 times more likely to develop primary liver cell carcinoma than $\mathrm{HBs}$ antigen negative subjects. ${ }^{8}$

Following the cloning of HBV-DNA, molecular hybridisation techniques were used to study the relationship of the viral DNA to the host genome. Initially several groups examined the Alexander primary liver cell carcinoma cell line, ${ }^{-11}$ and subsequently samples of primary liver cell

Address for correspondence: Dr H. C. Thomas. Department of Medicine, Royal Free Hospital, London NW3.

Received for publication 22 August 1983 carcinoma from patients in Africa, Europe, USA, and Asia. ${ }^{12}{ }^{13}$ The most striking feature of all these subjects was the presence of HBV-DNA integrated into the host genome. In rare cases episomal HBV-DNA was present. ${ }^{14}$ These studies were initially interpreted as evidence of direct oncogenic potential of the virus. Subsequently, tissues from chronically infected patients without evidence of malignant disease were studied and a variable prevalence of integration was found. ${ }^{15}$ Thus it became apparent that integration of HBV-DNA into the hepatocyte genome preceded development of primary liver cell carcinoma.

In the present study we have examined serum and liver tissue from patients with $\mathrm{HBe}$ antigen and antibody positive chronic $\mathrm{HBV}$ infection for the presence of, and molecular state of, HBV-DNA sequences. These data provide insight into the sequence of molecular events occurring during conversion from $\mathrm{HBe}$ antigenaemia to the phase of anti-HBe production when it occurs spontaneously and during therapy with adenine arabinoside mono- 
phosphate, and also on the stage when integrated sequences are detected.

\section{Methods}

PATIENTS

Serum samples and percutaneous liver biopsy cores were obtained from 22 patients with chronic HBV related liver disease and four with primary liver cell carcinoma. Clinical and histological details are shown in the Table. Serial serum specimens were collected from three additional patients undergoing therapy with adenine arabinoside monophosphate $10 \mathrm{mg} / \mathrm{kg} /$ day for five days, followed by $5 \mathrm{mg} / \mathrm{kg} /$ day for a further 23 days. ${ }^{16}$

\section{BIOCHEMICAL TESTS AND HBV SEROLOGICAL}

\section{MARKERS}

Biochemical tests were carried out by routine laboratory methods. $\mathrm{HBs}$ and $\mathrm{HBe}$ antigens and alphafetoprotein were detected and quantified by radioimmunoassay (Abbott and Hoerst Laboratories) and DNA polymerase was measured by the method described by Marion et al. ${ }^{17}$
ANALYSIS ÖF HBV-DNA SEQUENCES IN LIVER AND SERUM

Extraction of liver DNA and restriction endonuclease digestion

DNA was extracted from liver biopsy specimens and digested with either restriction endonuclease Hind III or EcoRI. ${ }^{18}$ Large molecular weight DNA was checked for size by agarose electrophoresis followed by staining with ethidium bromide. Restriction endonuclease digestion was similarly monitored by analysing approximately $1 \mu \mathrm{g}$ of DNA from the incubation mixture.

\section{Extraction of DNA from serum and dot hybridisation}

DNA was extracted from $0.25 \mathrm{ml} \mathrm{serum}^{19}$ and the final preparation dissolved in $20 \mu \mathrm{l}$ water. Dot hybridisation of one $\mu \mathrm{l}$ of these preparations was then undertaken. ${ }^{19}$

Agarose gel electrophoresis and Southern blotting Electrophoresis of DNA samples (20-50 $\mu \mathrm{g}$ of liver DNA, 2-8 $\mu$ l of serum DNA) was through $0.8 \%$ agarose gels. ${ }^{18}$ Each gel contained a sample of

Table Clinical, histological and serological details and molecular state of $H B V-D N A$ in liver

\begin{tabular}{|c|c|c|c|c|c|c|c|c|c|c|c|c|}
\hline \multirow{2}{*}{$\begin{array}{l}\text { Patient } \\
\text { (no) }\end{array}$} & \multicolumn{6}{|c|}{$H B V$ serology } & \multicolumn{2}{|c|}{ Liver $H B V-D N A$} & \multirow[b]{2}{*}{ Age } & \multirow[b]{2}{*}{ Sex } & \multirow[b]{2}{*}{ Origin } & \multirow[b]{2}{*}{ Histology } \\
\hline & $H B s A g$ & $H B e A g$ & $H B e A b$ & $D N A p$ & $H B V-D N A$ & $H B c A b$ & Free & Integrated & & & & \\
\hline 1 & + & + & - & + & + & + & + & - & 42 & $\mathbf{M}$ & British & $\mathrm{CAH}$ \\
\hline 2 & + & + & - & + & + & + & + & - & 23 & $\mathbf{M}$ & British & $\mathrm{CPH}$ \\
\hline 3 & + & + & - & + & + & + & + & - & 30 & $\mathrm{M}$ & Italian & $\mathrm{CAH}$ \\
\hline 4 & + & + & - & + & + & + & + & - & 37 & $\mathbf{M}$ & British & $\mathrm{CAH}$ \\
\hline 6 & + & + & - & - & + & + & + & + & 36 & $\mathbf{M}$ & Turkish & $\mathrm{CPH}$ \\
\hline 7 & + & + & - & + & + & + & + & - & 32 & $\mathbf{M}$ & British & $\mathrm{CPH}$ \\
\hline 8 & + & + & - & + & + & + & + & - & 30 & $\mathbf{M}$ & Dutch & $\mathrm{CPH}$ \\
\hline 9 & + & + & - & + & + & + & + & - & 32 & $\mathbf{M}$ & Greek & $\mathrm{CAH}$ \\
\hline 10 & + & + & - & + & + & + & + & - & 30 & $\mathbf{M}$ & British & $\mathrm{CAH}$ \\
\hline 11 & + & + & - & + & + & + & + & - & 29 & $\mathbf{F}$ & Saudi & $\mathrm{CAH}$ \\
\hline 12 & + & + & - & + & + & + & + & - & 43 & $\mathbf{M}$ & Malaysian & $\mathrm{CAH}$ \\
\hline 13 & + & + & - & + & + & + & + & - & 35 & $\mathbf{M}$ & British & $\mathrm{CAH}$ \\
\hline 15 & + & + & - & + & + & + & + & - & 42 & $\mathbf{M}$ & Indian & $\mathrm{CAH}$ \\
\hline 16 & + & - & + & + & + & + & + & - & 30 & $\mathbf{M}$ & British & $\mathrm{CAH}$ \\
\hline 17 & + & - & + & - & - & + & - & + & 23 & $\mathbf{M}$ & Spain & $\mathrm{CAH}$ \\
\hline 18 & + & - & + & - & - & + & - & + & 55 & $\mathbf{M}$ & Kuwait & Cirrhosis \\
\hline 19 & + & - & + & - & - & + & - & + & 50 & $\mathbf{M}$ & Iranian & Cirrhosis \\
\hline 20 & + & - & + & - & - & + & - & - & 61 & $\mathbf{M}$ & British & $\mathrm{CPH}$ \\
\hline 21 & + & - & + & - & - & + & - & - & 27 & $\mathbf{M}$ & Iranian & $\mathrm{CAH}$ \\
\hline 22 & + & - & + & - & - & + & - & - & 33 & $\mathbf{M}$ & Australian & $\mathrm{CAH}$ \\
\hline $23^{*}$ & + & $+\rightarrow-$ & $-\rightarrow+$ & $+\rightarrow-$ & $+\rightarrow-$ & + & NT & NT & 33 & $\mathbf{M}$ & Japanese & Cirrhosis active \\
\hline $24^{*}$ & + & $+\rightarrow-$ & $-\rightarrow+$ & $+\rightarrow-$ & $+\rightarrow-$ & + & NT & NT & 25 & $\mathrm{M}$ & British & $\mathrm{CAH}$ \\
\hline $25^{*}$ & + & $+\rightarrow-$ & $-\rightarrow+$ & $+\rightarrow-$ & $+\rightarrow-$ & + & NT & NT & 28 & $\mathbf{M}$ & British & $\mathrm{CAH}$ \\
\hline 26 & - & - & + & - & - & + & - & + & 63 & $\mathbf{M}$ & Nigerian & PLC + CALD \\
\hline 27 & - & - & + & - & - & + & - & + & 58 & $\mathbf{M}$ & British & PLC+CALD \\
\hline 28 & - & - & - & - & - & - & - & - & 72 & $\mathbf{F}$ & British & $\mathrm{PLC}+\mathrm{PBC}$ \\
\hline 29 & - & - & - & - & - & - & - & - & 36 & $\mathbf{F}$ & British & PLC + lupoid CALD \\
\hline
\end{tabular}

* Treated with ARA-AMP

NT = not tested, DNAp = HBV-DNA polymerase. 
bacteriophage DNA digested with Hind III, $20 \mu \mathrm{g}$ of the human hepatoma cell line (PLC/PRF/5) DNA digested with either Hind III or EcoRI and approximately $2-5 \mathrm{pg}$ of plasmid $\mathrm{pBH} 20-\mathrm{HBV}$ DNA digested with EcoRI.

After electrophoresis, the gels were stained with ethidium bromide, photographed and blotted according to Wahl's modification of the method of Southern. ${ }^{20}$

\section{Preparation of ${ }^{32} p-H B V-D N A$ probes and}

hybridisation

The ${ }^{32} \mathrm{p}$-HBV-DNA probes were prepared by nick translation ${ }^{21}$ of HBV-DNA that had been purified from plasmid pBH20-HBV-DNA after digestion with EcoRI. ${ }^{18}$ The probes had specific activities of $2-3 \times 10^{8} \mathrm{cpm} / \mu \mathrm{g}$ HBV-DNA.

Hybridisation to Southern blots was carried out in the presence of dextran sulphate ${ }^{20}$ and autoradiography was with preflashed Fuji Rx film and Fuji Mach II intensifying screen at $-70^{\circ} \mathrm{C}^{22}$ for varying lengths of time.

\section{Results}

\section{HBV RELATED CHRONIC LIVER DISEASE}

(a) $\mathrm{HBe}$ antigen positive patients (Fig. 1).

All had chronic hepatitis (Table) without evidence of primary hepatocellular carcinoma. A smear of HBV-DNA ranging from 2.8 to $2.0 \mathrm{~Kb}$ in size was seen in the sera of all these patients (Fig. 1B). There was no $3 \cdot 2 \mathrm{~Kb}$ band but a discrete band at $2 \cdot 1 \mathrm{~Kb}$ was visible. The mobility of this band was unaltered by digestion with EcoRI.

Free HBV-DNA was found in the liver tissue of all of the $\mathrm{HBe}$ antigen positive patients (Fig. 1A). The pattern in these patients was characterised by a prominent $3.2 \mathrm{~Kb}$ band and two smears varying from 2.8 to $2.0 \mathrm{~Kb}$ and 1.6 to $0.4 \mathrm{~Kb}$. Superimposed on the upper smear was a single discrete band at $2 \cdot 1$ $\mathrm{Kb}$ and on the lower smear two less well defined bands at 1.8 and $1.6 \mathrm{~Kb}$. The $2 \cdot 1 \mathrm{~Kb}$ band was also present after EcoRI digestion.

In one $\mathrm{HBe}$ antigen positive Turkish patient, HBV-DNA sequences were also shown in the higher

A

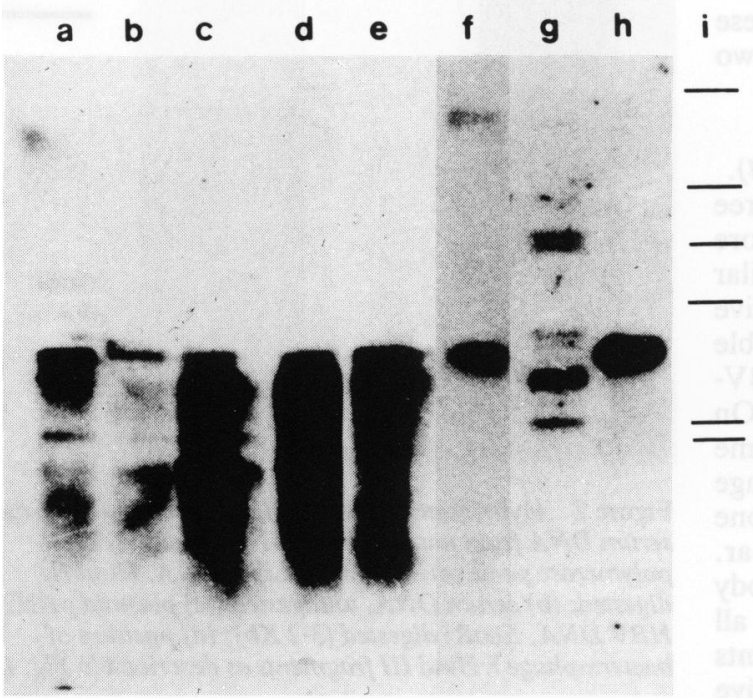

B

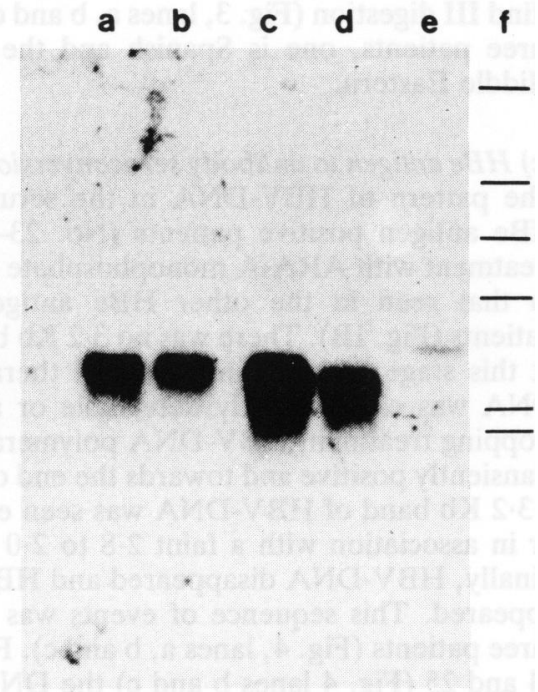

Figure 1 Examples of hybridisation pattern of $H B V D N A$ probes to liver and serum DNA from $H B e$ antigen positive patients with chronic $H B V$ infection.

(A) Liver DNA: lanes (a) patient 1 EcoRI digested; (b) patient 2, EcoRI digested; (c) patient 3, EcoRI digested; (d) patient 4 , Hind III digested; $(e)$ patient 5 , Hind III digested; $(f)$ patient 6 , Hind III digested; $(g)$ human hepatoma cell line PLC/PRF/5 DNA, EcoRI digested; (h) plasmid pBH2O-HBV DNA, EcoRI digested (3.2 Kb); (i) position of bacteriophage $\lambda$ Hind III fragments (from top: 23.5, 9.7, 6.6, 4.3, 2.2, 2.1 Kb). Liver DNA extracted from patients 7-15 showed similar patterns to those shown above for patients 2-5.

(B) Serum DNA: lanes (a) patient 2; (b) patient 3; (c) patient 7; (d) patient 5; (e) plasmid pBH2O-HBV DNA EcoRI digested $(3 \cdot 2 \mathrm{~Kb}) ;(f)$ positions of bacteriophage $\lambda$ Hind III fragments as described in Part A of this figure. Serum DNA from patients 1, 4, 6, and 8-15 gave hybridisation patterns similar to those shown above. 
molecular weight regions of the gel $(>3.2 \mathrm{~Kb})$ (Fig. 1A, lane f).

In this patient (No. 6 in Table) the two low molecular weight smears which are characteristically found in $\mathrm{HBe}$ antigen positive patients, were absent in spite of the presence of the $3.2 \mathrm{~Kb}$ band. Two faint bands visible in lane a of Figure 1A were artefacts which were not present on further filters prepared from this patient's liver DNA.

(b) HBe antibody positive patients (Figs. 2 and 3)

Seven patients with chronic liver disease, without liver tumours were examined. Six were negative for HBV-DNA in serum. In the remaining patient (No. 16 in Table) who was HBV-DNA polymerase positive, HBV-DNA was present in the serum in the form of a $2 \cdot 8$ to $2.0 \mathrm{~Kb}$ smear (Fig. 2, lane b).

Free HBV-DNA was not detected in liver tissue from all six patients who were also HBV-DNA and HBV-DNA polymerase negative in serum. The results for five of these patients (No. 17-21) are shown in Fig. 3 lanes a-e. In patient 16, who was positive for HBV-DNA in serum, free HBV-DNA was also present in the liver (Fig. 2, lane a). In three patients (No. 17, 18 and 19), HBV-DNA sequences were found in high molecular weight DNA after Hind III digestion (Fig. 3, lanes a, b and c). Of these three patients, one is Spanish and the other two Middle Eastern.

(c) $\mathrm{HBe}$ antigen to antibody seroconversion (Fig. 4). The pattern of HBV-DNA in the serum in three $\mathrm{HBe}$ antigen positive patients (No. 23-25) before treatment with ARA-A monophosphate was similar to that seen in the other $\mathrm{HBe}$ antigen positive patients (Fig. 1B). There was no $3.2 \mathrm{~Kb}$ band visible at this stage. After four weeks of therapy, HBVDNA was either weakly detectable or absent. On stopping treatment HBV-DNA polymerase became transiently positive and towards the end of this stage a $3.2 \mathrm{~Kb}$ band of HBV-DNA was seen either alone or in association with a faint 2.8 to $2.0 \mathrm{~Kb}$ smear. Finally, HBV-DNA disappeared and $\mathrm{HBe}$ antibody appeared. This sequence of events was seen in all three patients (Fig. 4, lanes a, b and c). For patients 24 and 25 (Fig. 4 lanes $b$ and $c$ ) the DNA negative tracks post treatment were omitted. In every case HBV-DNA in serum has remained negative in subsequent follow-up.

\section{PRIMARY LIVER CELL CARCINOMA}

Two of the four liver cell carcinomas contained HBV-DNA sequences in the high molecular weight DNA (Fig. 5, lanes a and b). In the two that were initially negative, the DNA load on the gel was

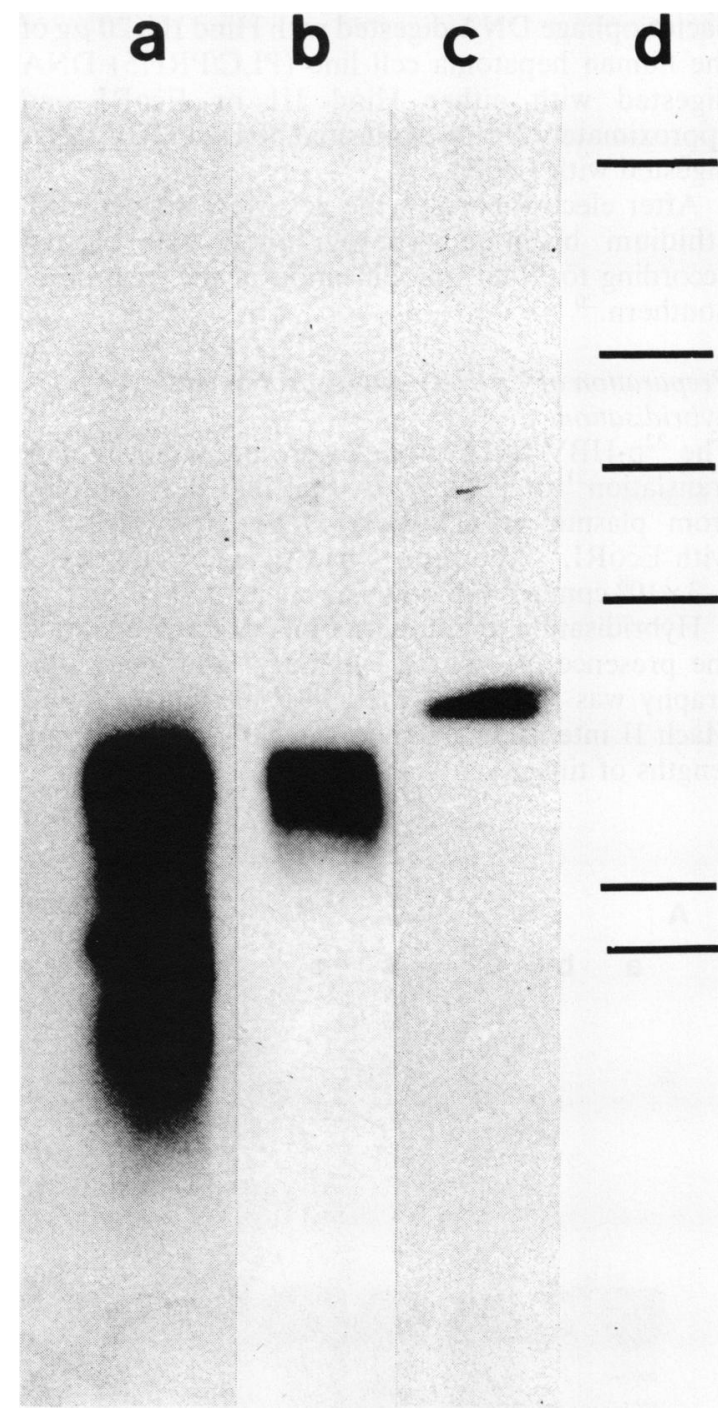

Figure 2 Hybridisation of $H B V D N A$ probe to liver and serum DNA from patient 16 (anti-HBe positive, DNA polymerase positive). Lanes (a) Liver DNA, Hind III digested; (b) serum DNA, undigested; (c) plasmid pBH2O$H B V D N A, E c o R I$ digested (3.2 Kb); (d) position of bacteriophage $\lambda$ Hind III fragments as described in Fig. 1.

increased from 20 to $50 \mu \mathrm{g}$, but these remained negative for HBV-DNA sequences.

\section{Discussion}

In the patients with $\mathrm{HBe}$ antigen positive chronic HBV infection, the pattern of viral DNA in the liver 
Figure 3 Hybridisation of $H B V-D N A$ probe to liver DNA from $\mathrm{HBe}$ antibody positive patients. (a) Patient 17, Hind III digested; (b) patient 18, Hind III digested; (c) patient 19, Hind III digested; (d) patient 20, Hind III digested; (e) patient 21, Hind III digested; (f) PLC/PRF/5 cell line DNA, EcoRI digested; $(g)$ plasmid pBH20-HBV-DNA EcoRI digested $(3 \cdot 2 \mathrm{~Kb}) ;(\mathrm{h})$ position of bacteriophage $\lambda$ Hind III fragments as described in Fig. 1. Liver DNA from patient 22 showed an $\mathrm{HBV}$ hybridisation signal (not shown). Sera from patients 17 to 22 were negative for $\mathrm{HBV}$. DNA when analysed by dot hybridisation (not shown) and where therefore not analysed by gel electrophoresis.

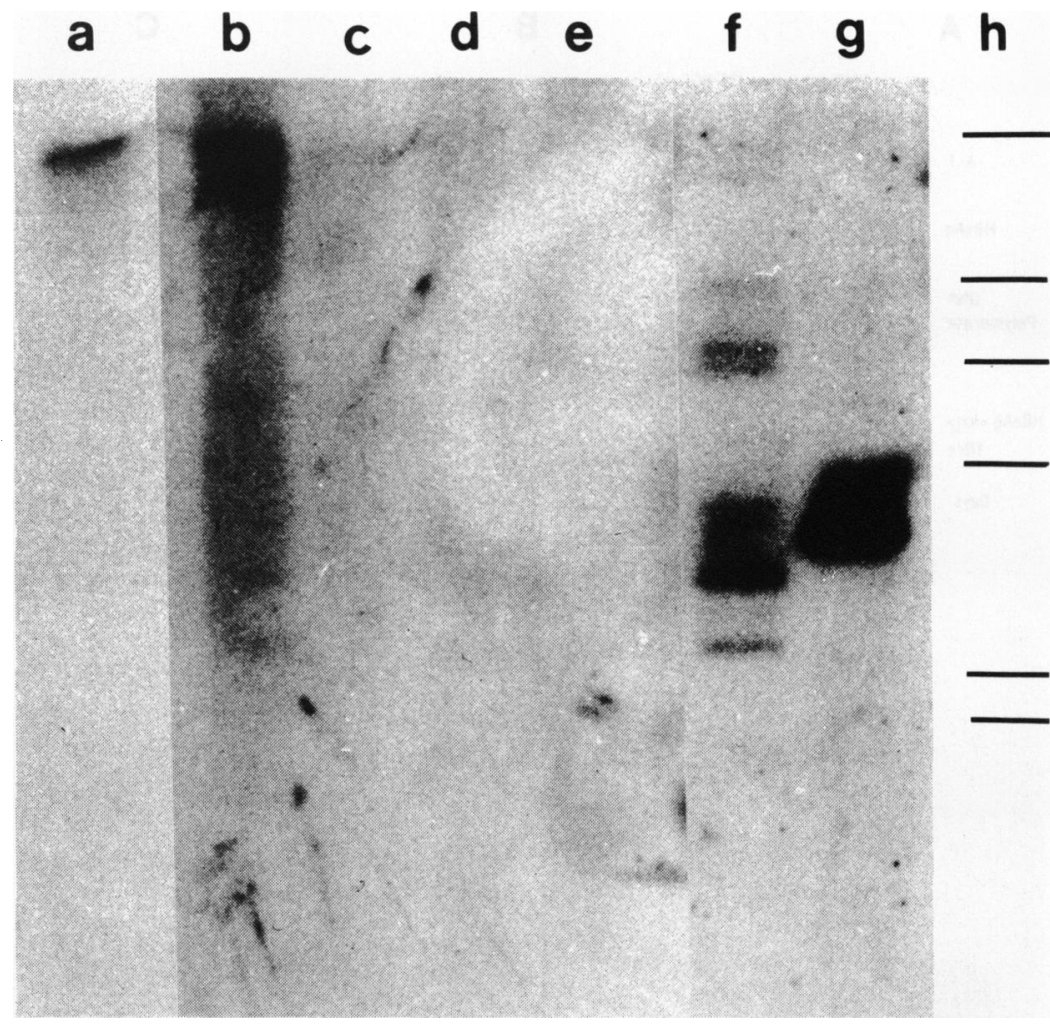

tissue was similar to that described in $\mathrm{HBe}$ antigen positive chimpanzees. ${ }^{23} 18$ The pattern was that of free DNA molecules as indicated by bands at 3.2 $\mathrm{Kb}$, a short smear from 2.8 to $2.0 \mathrm{~Kb}$ and a large smear further down the gel $(1.6 \mathrm{~Kb}$ and below), and also bands of discrete size below $3.2 \mathrm{~Kb}$ superimposed on the two smears. All these species, including the discrete bands, were seen in EcoRI digested as well as undigested and Hind III digested samples and therefore cannot be ascribed to the presence of supercoiled HBV-DNA. ${ }^{24}$ No bands at $3.4 \mathrm{~Kb}$ or $4.1 \mathrm{~Kb}$, previously reported by Shouval $e t$ $a l,{ }^{25}$ were seen in this study. The $3.2 \mathrm{~Kb}$ bands which are either linear or relaxed circular forms of HBV-DNA were not seen in the serum and therefore appear to be replicative intermediates which, at this stage, are only found in the liver. Only one patient of Turkish origin had integrated HBV-DNA sequences. These data are concordant with those published $^{13} 15$ in showing a low prevalence of detectable integrated HBV-DNA sequences in patients examined during the $\mathrm{HBe}$ antigenaemic phase of the infection. Indeed, if those with primary liver cell carcinoma are excluded, the number of published cases with integrated HBV-DNA at this stage of the infection, is very small. In addition, negative findings in $\mathrm{HBe}$ antigen positive chimpanzees ${ }^{23} 18$ further emphasise the need for more studies in this area before a definitive conclusion can be reached on whether integration of HBV-DNA sequences occurs in these $\mathrm{HBe}$ antigen positive patients.

Seven patients were examined during the latter stage of the disease when they had developed $\mathrm{HBe}$ antibody. One such patient was still HBV-DNA and HBV-DNA polymerase positive in serum and had free HBV-DNA present in the liver tissue. The remaining patients did not have detectable quantities of free HBV-DNA in their livers, but in three, integrated sequences were found. These patients were of Arabic, Spanish, or Iranian nationality and had probably been HBV infected since childhood. One patient with integrated sequences had been treated with ARA-A monophosphate and had undergone $\mathrm{HBe}$ antigen to antibody seroconversion within the last six months.

Of the 18 British patients, both $\mathrm{HBe}$ antigen and antibody positive groups, none had detectable integrated HBV sequences. The majority of these patients were homosexuals aged $20-40$ years and 
A
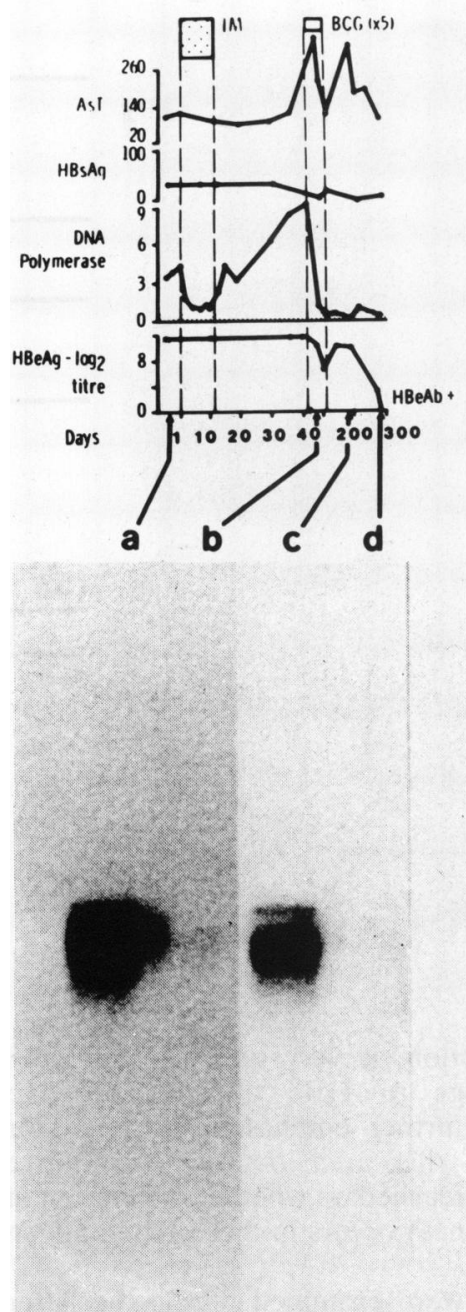

B
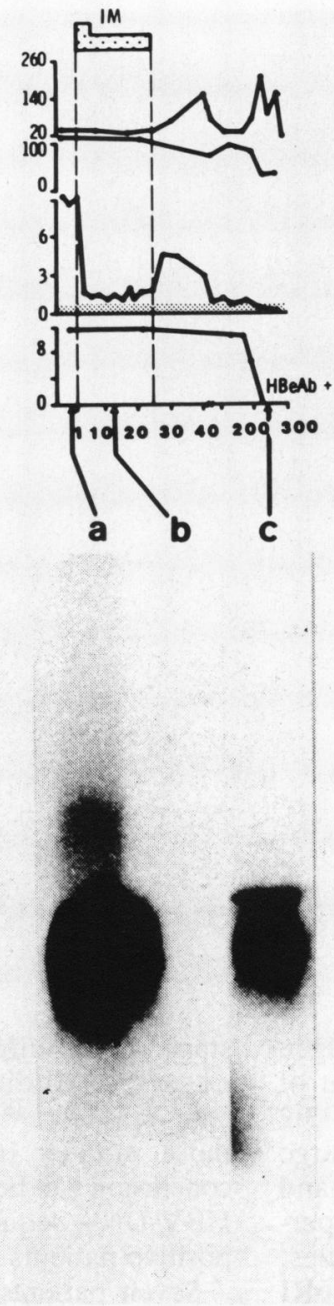

C

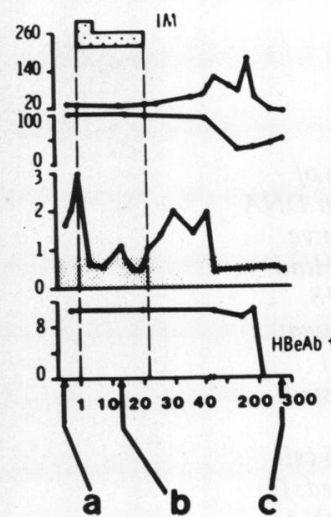

a

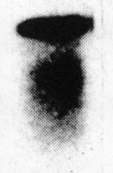

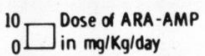

12 hourly

[马] daily Units -

- Ast iulL

- HBSAg \% control DNA Polymerase $\mathrm{dpm} \times 103 / 200 \mu \mathrm{l}$

Figure 4 Hybridisation pattern of $H B V-D N A$ probe to serum $D N A$ from patients undergoing $H B e$ antigen to $H B e$ antibody seroconversion. Upper panels: changes in AST, HBsAg, HBV-DNA polymerase and HBe antigen titres during antiviral therapy. Lower panel: hybridisation patterns of $H B V-D N A$ probe to Southern blots of $5 \mu$ l of serum DNA taken at various times and exposed for different lengths of time. $(A)$ Patient 23 treated with $A R A-A M P$ and $B C G ;(B)$ patients 24 treated with $A R A-A M P ;(C)$ patient 25 treated with $A R A-A M P ;(D)$ legends and (a) hybridisation of $H B V-D N A$ probe to plasmid pBH2O-HBV-DNA digested with EcoRI $(3 \cdot 2 \mathrm{~Kb}),(\mathrm{b})$ positions of bacteriophage $\lambda$ Hind III digestion products as described in Fig. 1.

had probably been infected as a result of their sexual activities. Thus in this group, in contrast with patients coming from the Mediterranean and Middle East, who were most probably infected in early life, the duration of HBV infection was likely to be less than 10 years. Further studies are indicated to determine whether the apparently higher prevalence of integrated HBV sequences in people of Arab,
Spanish and Iranian origins is related to the duration of the infection or to genetic factors.

During successful therapy with ARA-A monophosphate ${ }^{16}$ three patients developed a $3 \cdot 2 \mathrm{~Kb}$ band as the 2.8 to $2.0 \mathrm{~Kb}$ smear molecules were disappearing from the serum and as the transaminasès became raised. Finally, after development of $\mathrm{HBe}$ antibody and return of transaminases to 

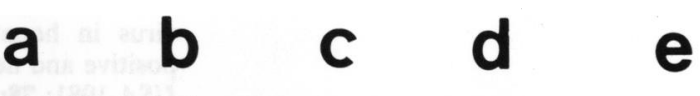

Figure 5 Hybridisation of $H B V-D N A$ probe to tumour $D N A$ from patients with primary liver cell carcinoma. (a) Patient 26, Hind III digested; (b) patient 27, Hind III digested; (c) patient 27 EcoRI digested; (d) PLC/PRF/ 5 cell line DNA Hind III digested; (e) plasmid pBH2O$H B V$-DNA EcoRI digested; (f) positions of bacteriophage $\lambda$ Hind III fragments as described in Fig. 1.

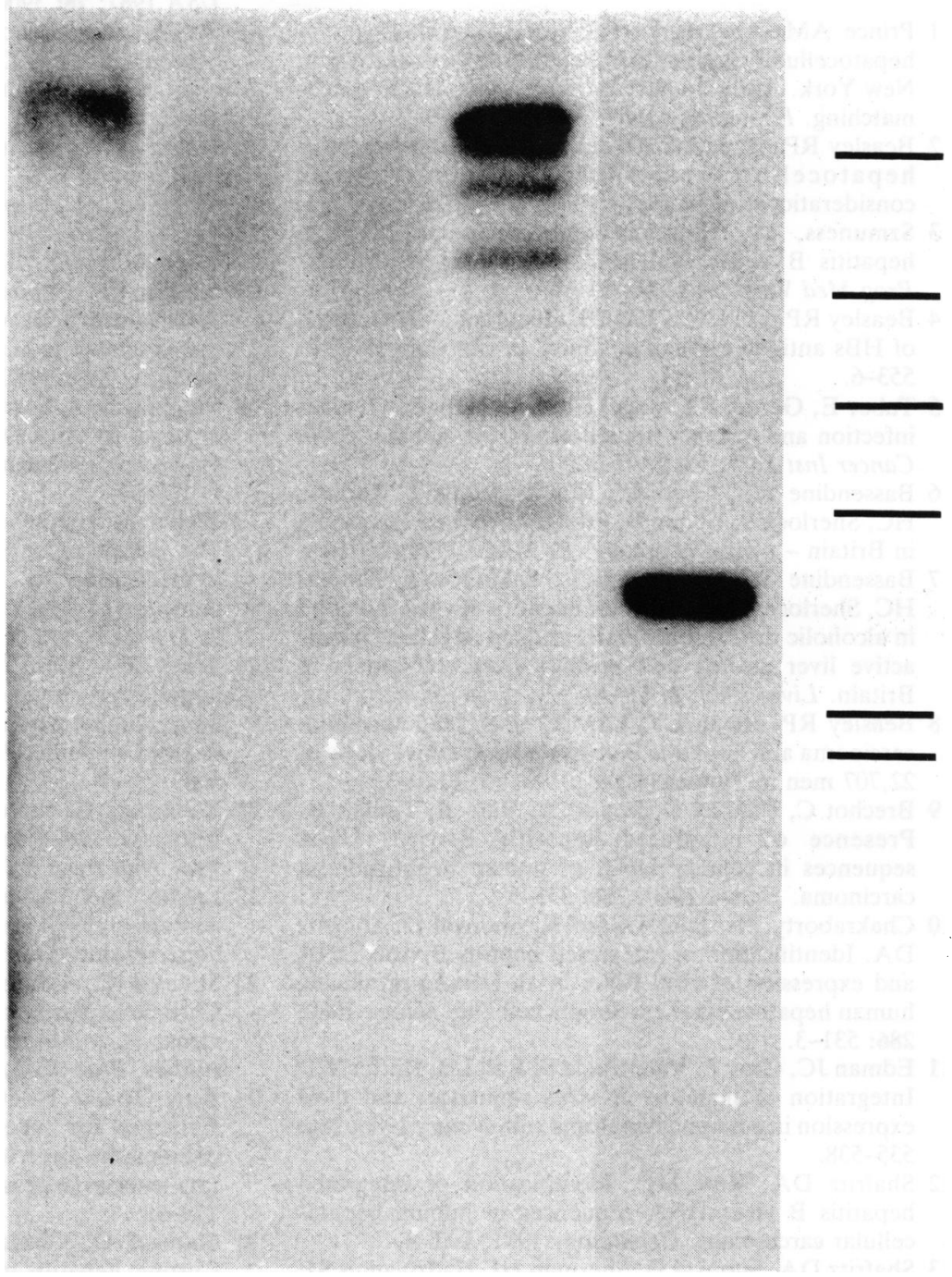

normal, free HBV-DNA disappeared both from the serum and liver. Whether the serum $3 \cdot 2 \mathrm{~Kb}$ band is a replicative intermediate transiently released into the serum during elimination of HBV replicating cells or is a reflection of the liver's ability to produce virus particles with a complete plus strand during low but not high level replication, remains to be determined.

Four patients with primary liver cell carcinoma were studied. All four were HBs antigen negative by radioimmunoassay but two were positive for anti$\mathrm{HBc}$ in the absence of anti-HBs. These two patients had integrated HBV-DNA sequences in their liver tissue whereas the two without serological markers of HBV infection were negative for HBV-DNA. The latter patients had autoimmune liver diseases (primary biliary cirrhosis and lupoid chronic active hepatitis) and had been treated with prednisolone and azathioprine. In these it seems improbable that HBV had a role and more likely that an immune defect underlay the development of the tumours. ${ }^{26}$

This work is supported by the Cancer Research Campaign. HCT is a Senior Wellcome Fellow in Clinical Science, and IVDW an MRC Fellow. 


\section{References}

1 Prince AM, Alcabes P. The risk of development of hepatocellular carcinoma in hepatitis $B$ virus carriers in New York. A preliminary estimate using death records matching. Hepatology 1982; 2: 15S-20S.

2 Beasley RP. Hepatitis B virus as the etiologic agent in hepatocellular carcinoma - epidemiologic considerations. Hepatology 1982; 2: 21S-26S.

3 Szmuness, W. Hepatocellular carcinoma and the hepatitis B virus: evidence for a causal association. Prog Med Virol 1978; 24: 40-69.

4 Beasley RP, Lin CC, Chin CS. Geographic distribution of HBs antigen carriers in China. Hepatology 1982; 2: 553-6.

5 Tabor E, Gerety RJ, Vogel CL et al. Hepatitis B virus infection and primary hepatocellular carcinoma. $J$ Nat Cancer Inst 1977; 58: 1197-1200.

6 Bassendine MF, Chadwick RG, Lapriotis T, Thomas HC, Sherlock S, Cohen B. Primary liver cell carcinoma in Britain - a viral aetiology. Br Med J 1979; 1: 166.

7 Bassendine MF, Della Seta L, Salmeron J, Thomas $\mathrm{HC}$, Sherlock S. Incidence of hepatitis B virus infection in alcoholic liver disease, HBs antigen negative chronic active liver disease and primary liver cell cancer in Britain. Liver 1983; 3: 65-70.

8 Beasley RP, Hwan LY, Lin CC et al. Hepatocellular carcinoma and hepatitis B virus - a prospective study of 22,707 men in Taiwan. Lancet 1981; 2: 1129-33.

9 Brechot C, Pourcel C, Louise A, Rain B, Tiollais R. Presence of integrated hepatitis $B$ virus DNA sequences in cellular DNA of human hepatocellular carcinoma. Nature 1980; 286: 533-5.

10 Chakraborty PR, Ruiz-Opazo N, Shouval D, Shafritz DA. Identification of integrated heptitis $B$ virus DNA and expression of viral RNA in an HBsAg-producing human hepatocellular carcinoma cell line. Nature 1980; 286: 531-3.

11 Edman JC, Gray P, Valenzuela P, Rall LB, Rutter WJ. Integration of hepatitis $B$ virus sequences and their expression in a human hepatoma cell. Nature 1980; 286: 535-538.

12 Shafritz DA, Kew MC. Identification of integrated hepatitis B virus DNA sequences in human hepatocellular carcinomas. Hepatology 1981; 1: 1-8.

13 Shafritz DA, Shouval D, Sherman HI, Hadziyannis SJ, Dew MC. Integration of hepatitis B virus DNA into the genome of liver cells in chronic liver disease and hepatocellular carcinoma. $N$ Engl J Med 1981; 305: 1067-73.

14 Brechot C, Hadchoval M, Scotto J. State of hepatitis B virus in hepatocytes of patients with $\mathrm{HBs}$ antigen positive and negative liver disease. Proc Natl Acad Sci USA 1981; 78: 3906-10.

15 Brechot C, Hadchovel M, Scotto J et al. Detection of hepatitis B virus DNA in liver and serum: a direct appraisal of the chronic carrier state. Lancet 1981; 2: 765-7.

16 Weller IVD, Bassendine MF, Craxi A et al. Successful treatment of $\mathrm{HBs}$ and $\mathrm{HBe}$ antigen positive chronic liver disease: prolonged inhibition of viral replication by highly soluble adenine arabinoside 5monophosphate. Gut 1982; 23: 717-28.

17 Marion PL, Oshiro LS, Regnary DC, Scullard GH, Robinson WS. A virus in Beechery ground squirrels that is related to hepatitis B virus of humans. Proc Natl Acad Sci USA 1980; 77: 2941-5.

18 Monjardino J, Fowler MJF, Montano L et al. Analysis of hepatitis virus DNA in the liver and serum of $\mathrm{HBe}$ antigen positive chimpanzee carriers. J Med Virol 1982; 9: 189-99.

19 Weller IVD, Fowler MJF, Monjardino J, Thomas HC. The detection of HBV-DNA in serum by molecular hybridisation: a more sensitive method for the detection of complete HBV particles. J Med Virol 1982; 9: 273-80.

20 Wahl GM, Stern M, Stark SR. Efficient transfer of large DNA fragments from agarose gels to diazobenzylmethyl-paper and rapid hybridisation by using dextran sulphate. Proc Natl Acad Sci USA. 1979; 76: 3683-7.

21 Weinstock R, Sweet R, Weiss M, Cedar H, Axel R. Intragenic DNA spaces interrupt the ovalbumin gene. Proc Natl Acad Sci USA. 1978; 75: 1299-1303.

22 Laskey RA, Mills A. Enhanced autoradiographic detection of ${ }^{32} \mathrm{p}$ and ${ }^{125} \mathrm{I}$ using intensifying serum and hypersensitized film. FEBS Letters 1977; 82: 314-6.

23 Shouval D, Chakraborty PR, Puiz-Opazo $\mathrm{N}$ et al. Chronic hepatitis in chimpanzee carriers of hepatitis $B$ virus: morphologic immunologic and viral DNA studies. Proc Natl Acad Sci USA 1980; 77: 6147-51.

24 Ruiz-Opazo N, Chakraborty PR, Shafritz DA. Evidence for supercoiled hepatitis B virus DNA in chimpanzee liver and serum Dane particles: possible implications in persistent HBV infection. Cell 1982; 29: 129-38.

25 Shouval D, Chakraborty PR, Puiz-Opazo $\mathrm{N}$ et al. Chronic hepatitis in chimpanzee carriers of hepatitis $\mathrm{B}$ virus - morphologic, immunologic and viral DNA studies. Proc Natl Acad Sci USA 1980; 77: 6147-51.

26 Burroughs AK, Bassendine MF, Thomas HC, Sherlock S. Primary liver cell cancer in autoimmune chronic liver disease. Br Med J 1981; 282: 273-5. 